logos_i_ethos_2_(33)_2012, s. 253-262

Mirosław Twardowski

\title{
Geniusze zwyczajni czy nadzwyczajni?
}

\section{Gino Segrè, Ordinary Geniuses. Max Delbrück, George Gamow, and the Origins of Genomics and Big Bang Cosmology, Viking Penguin, London 2011, ss. 330.}

W ostatnim czasie na rynku wydawniczym ukazała się książka włoskiego przyrodnika Gino Segrègo Zwyczajni geniusze. Max ks. Mirosław Twardowski - dr, adiunkt w Zakładzie Polityki Regionalnej i Gospodarki Żywnościowej Uniwersytetu Rzeszowskiego.

Delbrück, George Gamow i naro-

dziny genomiki i kosmologii Wielkiego Wybuchu'. Autor tej niezwykle interesującej pozycji jest profesorem fizyki i astronomii na Uniwersytecie w Pensylwanii. Swoją nową książkę rozpoczyna od intrygującego pytania: jakie są najbardziej ekscytujące obszary w nauce dzisiaj? I odpowiada: kosmologia - nauka o wszechświecie, i genomika - analiza genów organizmów żywych (s. XV-XVI). Pierwsza z wyżej wymienionych nauk zajmuje się światem w skali makro, ogromnym kosmosem, a druga światem w mikroskali, najmniejszymi strukturami składającymi się na byty ożywione. Kosmologia porusza największe nierozwiązane zagadnienie w fizyce, dotyczące bilansu masy-energii wszechświata. Cała obserwowana materia, taka jak gwiazdy, planety i pył, stanowi tylko 5\%; 95\% pozostałej masy nazywamy ciemną energią i ciemną materią, ponieważ te formy nie wydają się emitować jakiegoś rozpoznawalnego

Recenzowana książka nie jest pierwszą publikacją książkową tego autora. Wcześniej ukazały się dwie inne pozycje: A Matter of Degrees. What Temperature Reveals About the Past and Future of our Species, Planet and Universe, New York 2002, oraz Faust in Copenhagen. A Struggle for the Soul of Physics, New York 2007. 
sygnału. Ich zidentyfikowanie pewnie będzie punktem zwrotnym w naszym spojrzeniu na wszechświat. Genomika również nie znajduje odpowiedzi na wszystkie wysuwane w jej obrębie ważne pytania. Jednym z nich jest pytanie o sposób odcyfrowania zbioru instrukcji dla konstrukcji organizmów żywych.

Niezwykle ważny wkład w rozwój tych dwóch obszarów nauki wnieśli dwaj uczeni: Max Delbrück, Niemiec, i George Gamow, Rosjanin. Z wykształcenia byli fizykami, a później, choć w różnym stopniu, otworzyli się na inne obszary wiedzy, zwłaszcza biologię. Na kolejnych stronach swej książki Segrè opisuje chronologicznie wiele ciekawych wątków z osobistego i zawodowego życia obydwu badaczy. Gamow jest postacią dobrze znaną polskim czytelnikom ${ }^{2}$, dlatego nie wydaje się konieczne przedstawiać szczegółowej biografii rosyjskiego fizyka. Ograniczymy się tylko do krótkiego przedstawienia poglądów zorientowanych na fenomen życia, które są mniej znane czytelnikom, zwłaszcza w Polsce. Z kolei drugiemu z interesujących nas fizyków, Delbrückowi, jak dotąd nie poświęcono na gruncie polskim osobnego opracowania. Wydaje się więc uzasadnione zarysować krótko życiorys i drogę naukową niemieckiego fizyka, bazując na materiale zawartym w recenzowanej książce.

Max Delbrück urodził się w Berlinie 4 września 1906 r. Rodzina Delbrücka należała do najwyższej warstwy pruskiego mieszczaństwa. Dziadek jego matki, Justus von Liebig, był jednym z założycieli nowoczesnej chemii, a ojciec Maxa, Hans, był profesorem historii na uniwersytecie w Berlinie.

Delbrück zamierzał najpierw zostać astronomem, ale ostatecznie zdecydował się na studia z fizyki. Szczególnie fascynowała go powstająca wówczas mechanika kwantowa. W 1931 r., po ukończeniu studiów, przeniósł się z Berlina do Kopenhagi, żeby studiować fizykę atomową na tamtejszym uniwersytecie pod kierunkiem będącego wówczas u szczytu sławy duńskiego fizyka Nielsa Bohra. Długo nie mógł się pogodzić ze

W Polsce ukazały się przekłady kilku książek Gamowa: Materia, ziemia i niebo [tyt. oryg. Matter, Earth, and Sky], tłum. B. Wojtowicz-Natanson, Warszawa 1963; Biografia fizyki [tyt. oryg. Biography of Physics], tłum. B. Wojtowicz-Natanson, Warszawa 1967; Pan Tompkins w krainie czarów [tyt. oryg. Mr Tompkins in Paperback], tłum. M. J. Hurwic, B. Wojtowicz-Natanson, L. Natanson, M. Krośniak, Warszawa 1995. 
śmiercią ojca (1929 r.), co wyjaśniałoby po części relacje oparte na zasadzie ojciec-syn, mentor-uczeń, jakie rozwinął później z Bohrem (zob. s. 49). W sierpniu 1932 r. Delbrück wysłuchał wykładu Bohra Światło $i \dot{z} y c i e$ (Light and Life), wygłoszonego na kongresie fototerapeutów, poświęconego roli światła w „biologii, biofizyce i terapii” (s. 52). Młody fizyk zainteresowany był sprawami poruszanymi na wykładzie duńskiego fizyka już od jakiegoś czasu. Jednak przemyślenia Bohra na ten temat, szczególnie wezwania, by odkryć komplementarność w biologii, wywarły duży wpływ na dalszą karierę naukową niemieckiego fizyka. Od tego czasu zaczął angażować się w poważne dyskusje z biologami, chemikami i fizykami na tematy związane $z$ fenomenem życia. Wśród nich byli m.in. Karl Zimmer, młody specjalista od promieniowania, oraz Nikolai Timofiejew-Riesowski, bardzo ceniony genetyk. Współpraca Delbrücka z tymi dwoma badaczami doprowadziła do powstania w 1935 r. ważnej pracy On the Nature of Gene Mutation and Gene Structure (O naturze mutacji genowych i strukturze genu), nazywana czasem "pracą Trzech” (Three-Man-Labor) (s. 61). Publikacja ta zyskała popularność nie tyle ze względu na swoją treść, lecz na wpływ, jaki wywarła na cieszącym się ogromnym autorytetem w całym ówczesnym naukowym świecie austriackim fizyku Erwinie Schrödingerze. W liczącej dziewięćdziesiąt stron książeczce, zatytułowanej What is Life (Czym jest życie?) Schrödinger przedstawiał poglądy Delbrücka i jego kolegów, co przyczyniło się do ich spopularyzowania wśród młodego pokolenia naukowców.

W 1937 r. Delbrück pojechał do Caltech w Stanach Zjednoczonych w celu kontynuowania swoich badań laboratoryjnych nad muszką owocową (Drosophila melanogaster) i stał się szybko jednym z najbardziej wpływowych biologów na świecie. Relacje między Delbrückiem a Drosofilistami nie układały się dobrze. Dzięki Emory Ellis Delbrück szybko zdał sobie sprawę, że nie Drosophila, ale fag Coli jest idealnym systemem biologicznym, na którym można przeprowadzać badania ilościowe. Były to proste testy na bakteriach gospodarza oraz faga. Doświadczenie można było przeprowadzić w jeden dzień, techniki były proste do nauczenia, a dodatkowym profitem dla fizyka był fakt, że zarówno fag, jak i bakteria były nieszkodliwe. W związku z tymi badaniami Delbrück 
wraz z Salwadorem Lurią i Alfredem Hershey’em w kwietniu 1943 r. założył Grupę fagową. Późniejszy członek Grupy, lata po śmierci trzech założycieli, scharakteryzował ich następująco:

Kościół fagowy (The Phage Church), jak nas nieraz nazywają, prowadzony był przez trójcę: Delbrücka, Lurię i Hershey’a. Pozycja założyciela, Delbrücka, oraz jego oficjalny manieryzm czyniły z niego papieża, Luria był ciężko pracującym, wrażliwym społecznie księdzem-spowiednikiem. Hershey był świętym³ .

Pierwszym miejscem „kultu” Kościoła fagowego było Cold Spring Harbor. Latem 1945 r. zorganizowano tam kilkudniowy kurs, przedłużony następnego roku do trzech tygodni, który stał się stałym elementem Cold Spring Harbor, odbywającym się każdego lata przez następne dwadzieścia sześć lat. Było to niezwykłe zgrupowanie badaczy, w którym początkujący absolwenci studiów uniwersyteckich oraz profesorowie o ugruntowanej już pozycji w świecie nauki pracowali ramię w ramię.

Delbrück był najbardziej stanowczym krytykiem w Cold Spring Harbor (zob. s. 140-141). Największym wkładem w rozwój genetyki bakterii była, zdaniem Segrè, inteligencja niemieckiego naukowca oraz krytyczne nastawienie, które przyjmował podczas seminariów oraz przy ocenianiu prac innych. Uważał, że zaakceptować daną teorię należy tylko wówczas, gdy zaproponuje się i przeprowadzi ze skutkiem negatywnym eksperyment mający na celu jej odparcie. W relacjach z Delbrückiem w sprawach naukowych trzeba było nauczyć się bronić swego zdania. Działania niezdecydowane nie były tolerowane. W roku 1948 dokonania Delbrücka w Caltech i Cold Spring Harbor czyniły już z niego kultową postać w biologii molekularnej (zob. s. 172). Posiadał także taką charyzmę, iż wielu jego zwolenników zaczęło odczuwać wobec jego osoby to samo co James Watson, gdy pisał, że jest on „wzorem tego, czego oczekiwałem po swoim życiu”".

F. Stahl, Alfred Hershey, [w:] Biographical Memoirs of the National Academy of Sciences, National Academies Press: Washington, vol. 80, 2001, s. 142-59; cyt. za: G. Segrè, Ordinary Geniuses..., dz. cyt., s. 137.

4 J. D. Watson, A Passion for DNA: Genes, Genomes, and Society, Cold Spring Harbor 2000, s. 213; cyt. za: G. Segrè, Ordinary Geniuses..., dz. cyt., s. 172. 
Segrè na kartach swej książki przekonuje, że w głębi serca Delbrück do końca pozostał fizykiem lub przynajmniej podobała mu się niejednoznaczność tego, czy był fizykiem, czy biologiem (zob. s. 230). W styczniu 1947 r. napisał do Bohra, że początek kariery w Caltech zakończył jego metamorfozę z fizyka w biologa. Jednak trzy lata później, kiedy w $1949 \mathrm{r}$. wraz z kompozytorem Paulem Hindemithem oraz poetą Wallacem Stevensem przemawiał na jubileuszowym spotkaniu Akademii Sztuki i Nauki Connecticut, postanowił zatytułować swoją mowę A Physicist Looks at Biology (Spojrzenie fizyka na biologię). Nawet dwie dekady później, w 1969 r., przemawiał na temat A Physicist's Renewed Look at Biology: Twenty Years Later (Nowe spojrzenie fizyka na biologię: dwadzieścia lat później). Segrè podsumowuje swą myśl, że nawet we własnych oczach Delbrück nigdy nie uznał swej metamorfozy za zakończoną.

Delbrück postrzegał wszystkie organizmy jako części kontinuum, różniące się od siebie przynajmniej w niewielkiej części, jednak połączone ewolucją (zob. s. 231). Dlatego uważał, że w biologii nie ma „zjawisk absolutnych", jak zwykł nazywać rzeczy dziejące się w kółko w ten sam sposób. $Z$ drugiej strony, uważał, że w fizyce jest mnóstwo takich zjawisk. Każdy atom wodoru, czy to w szklance wody, czy na ogromnej powierzchni, nie różni się niczym od pozostałych, a rządzące nimi prawa nigdy się nie zmieniają. "Zjawiska absolutne” ułatwiały identyfikację tego, co Delbrück zwykł nazywać „wyraźnymi paradoksami”, czyli rzeczami, które nie pasują do przyjętych schematów. Z jego mowy w 1949 r. w Akademii Connecticut wynika, że to właśnie poszukiwanie takich paradoksów przyciągnęło go do biologii.

Ku zdziwieniu Delbrücka mechanizm replikacji genetycznej, wynikający ze struktury DNA, nie wykazywał żadnych ,wyraźnych paradoksów", nie wymagał też nowych praw fizyki lub chemii. Z pokorą uczony uznał wówczas, że musi szukać gdzie indziej czegoś, co w biologii wskazałoby na „wyraźny paradoks (zob. s. 231-232). Wybrał do tego fizjologię zmysłów, rozpoczynając od pytania, jak proste organizmy reagują na bodźce. Był to ciekawy wybór, warty głębokich przemyśleń, które charakteryzowały jego podejście do innych problemów naukowych. Zaczął postępować podobnie, jak robił to w przypadku fagów, gromadząc 
wokół siebie niewielką grupę badaczy otwartych na swobodną dyskusję, która od zawsze stanowiła znak rozpoznawczy jego pracy. Fizjologia zmysłów zajęła sporą część uwagi Delbrücka przez resztę jego kariery badawczej. Organizm, który zdecydował się badać, grzyb Phycomyces, nie dostarczył żadnych odpowiedzi. Wyniki były bardzo interesujące, jednak nie doprowadziły do odkrycia „behawioralnego atomu wodoru”, na co tak bardzo liczył.

Chociaż badania Delbrücka w połowie lat pięćdziesiątych ubiegłego wieku nie były tak wpływowe jak jego wcześniejsze prace, to jednak w późniejszych latach spotkał się ze sporym uznaniem. W 1969 r. wraz z Hersheyem i Lurią, współtwórcami Grupy fagowej, otrzymał Nagrodę Nobla w dziedzinie fizjologii i medycyny.

Drugi z interesujących nas fizyków, George Gamow, podobnie jak Delbrück, choć w dużo mniejszym stopniu, na pewnym etapie swojego życia zrobił odważny krok w stronę biologii. W swym otwarciu na problemy biologiczne pozostawał pod wpływem Czym jest $\dot{z} y c i e$ E. Schrödingera. W 1952 r. opublikował swoje przemyślenia biologiczne, wyraźnie inspirowane wspomnianą wyżej publikacją austriackiego fizyka, w książce zatytułowanej Mr. Tompkins Learns the Facts of Life. W tej pracy, jednej z całej serii, Gamow wykorzystuje fikcyjną postać Pana Tompkinsa, aby zaprezentować własne przemyślenia dotyczące dziedziny biologii. Tematem ostatniego rozdziału Wykład profesora. $\mathrm{Na}$ tura $\dot{z} y c i a^{5}$ jest związek między fenomenem życia a prawami fizyki. Streśćmy główne rozstrzygnięcia rosyjskiego fizyka w kwestii życia, zawarte w powyższym rozdziale wspomnianej książki .

Gamow jest przekonany, że problem życia zawsze był, i wciąż jest, największym wyzwaniem dla człowieka myślącego7. Według rosyjskiego badacza pierwszym i najważniejszym problemem, z jakim należy zmierzyć się przy interpretacji fenomenu życia, jest problem entropii. Na

\footnotetext{
G. Gamow, Mr Tompkins Learns the Facts of Life, Cambridge 1953, s. 66-88.

O tym, dlaczego właśnie Mr Tompkinsa wybrał na tytułowego bohatera swoich kilku książek, pisze Gamow w jednym z rozdziałów recenzowanej książki (Mr. Tompkins Arrives, s. 277-281). Zob. G. Gamow, Mr Tompkins..., dz. cyt., s. 69.
} 
pierwszy rzut oka wydaje się, że organizmy żywe zaprzeczają jednemu z najbardziej fundamentalnych praw fizyki: prawu stale wzrastającej entropii (prawu wzrastającego nieuporządkowania). Gamow odwołuje się do przykładu z ziarnem, które wsadzamy w glebę i wyrasta z niego wielki $\mathrm{daqb}^{8}$. Kompleksowe organiczne molekuły składające się na drzewo zbudowane są z atomów, które wcześniej tworzyły dwutlenek węgla zaabsorbowany przez jego liście, oraz molekuły wody i kilku prostych nieorganicznych soli wessanych przez jego korzenie. Mamy tutaj transformację z prostych molekularnych struktur powietrza, wody i soli do wysoce zorganizowanych struktur molekuł proteinowych i komórek roślinnych. Nie ma wątpliwości, podkreśla Gamow, że są bardziej uporządkowane niż ich składniki, a ich entropia spadła w procesie wzrostu. Do wzrastającego porządku molekularnego lub do spadającej entropii, charakteryzującej wzrost rośliny, mogą się również przyczynić promienie słoneczne ${ }^{9}$. Promieniowanie słoneczne docierające do Ziemi wykazuje bardzo duży deficyt zawartości entropii. Rośliny mogą wykorzystać ten deficyt entropii radiacji słonecznej w celu zredukowania własnej entropii. Promienie słoneczne padające na powierzchnię zielonych liści mogą dosłownie wessać nadmiar entropi, obniżając całkowitą entropię rośliny ${ }^{10}$. Oczywiście, proces niekoniecznie zachodzi sam z siebie, i to od rośliny zależy, czy wykorzysta ona ujemną entropię z radiacji słonecznej. Jednak rośliny są wystarczająco przystosowane pod tym względem i korzystają ze specjalnego procesu zwanego fotosyntezą, który wykorzystuje zarówno energię, jak i entropię promieni słonecznych, by budować kompleksowe struktury organiczne z dużo prostszych struktur nieorganicznych.

Zainteresowania biologiczne Gamowa zdecydowanie wykraczały poza tematy zawarte we wspomnianej książce Schrödingera. Szczególnie intrygowała go zagadka kodu genetycznego (zob. s. 209-218). W latach pięćdziesiątych XX w. Gamow wysunął przypuszczenie, że istnieje bezpośredni związek między sekwencjami nukleotydów w DNA

Zob. tamże, s. 73.

Zob. tamże, s. 75.

10 Zob. tamże, s. 77-78. 
a sekwencją aminokwasów w białku. Ideę Gamowa podjął Francis Crick, co doprowadziło ostatecznie do sformułowania w 1957 r. centralnego dogmatu biologii molekularnej, zgodnie z którym informacja genetyczna płynie w następującym kierunku: DNA $\rightarrow$ RNA $\rightarrow$ białko.

Książka Segrègo to nie barwny szkic dwóch niepowiązanych ze sobą życiorysów naukowych. Przez całą książkę przewija się wątek przyjaźni dwóch uczonych. Autor ze szczegółami opisuje między innymi pierwsze spotkanie Delbrücka i Gamowa:

To było w 1928 r. Dwudziestodwuletni Max Delbrück siedział przy stole w kawiarni w małym niemieckim mieście uniwersyteckim Getyndze ${ }^{11}$, kiedy przyjaciel przedstawił mu dziwnego młodego mężczyznę. To był Geo, dwudziestoczteroletni George Gamow, bardzo wysoki blondyn, z dużą głową i krótkowzrocznymi oczyma, które przymrużał za grubymi szkłami. Mało rosyjskich naukowców było w tym czasie na Zachodzie. Max był całkiem inny od fizyków, których już znał. Inaczej niż Geo, Max był od początku idealnym studentem w Getyndze. Był wysoki i przystojny, pochodził z wielkiej niemieckiej rodziny. Max zamierzał najpierw zostać astronomem, ale ostatecznie zdecydował się na studia z fizyki, podekscytowany powstającą wówczas mechaniką kwantową. Jednak ani Max, ani Geo nie czuli się w atmosferze Getyngi zupełnie tak jak w domu. Główny powód był taki, że nacisk na matematykę w rozwiązywaniu problemów fizyki był tym, co nie było wygodne dla żadnego z nich. Oni chcieli znaleźć własne podejścia do rozwiązywania problemów. Później pogłębiali swoją znajomość w Kopenhadze, stolicy Danii. Zaprzyjaźnili się tam, a nawet pracowali razem, by pójść później osobną drogą, by znowu spotkać się w ich nowym kraju, Stanach Zjednoczonych (s. 1-3).

Gamow przeszedł do historii jako ojciec kosmologii Wielkiego Wybuchu - pierwszy zauważył rozszerzanie się gorącego kotła wszechświata

11 Getynga (niem. Göttingen) w tamtym czasie była mekką fizyki, szczególnie dla badaczy z solidnym matematycznym przygotowaniem. Tradycję tę zapoczątkował wiek wcześniej Karl Friedrich Gauss, jeden z największych matematyków wszechczasów, ponadto jeden z najmocniej zainteresowanych fizycznymi problemami. Ta tradycja była kontynuowana przez jego następców, matematyków i fizyków teoretyków, Davida Hilbert i Maxa Borna. Zob. G. Segrè, Ordinary Geniuses..., dz. cyt., s. 2. 
w pierwszych minutach. Delbrück został ikoną badań nad bakteriofaga$\mathrm{mi}$, wirusami, które dostarczają najprostszego środka do studiowania genetycznej replikacji. Skoncentrowanie badań na tych wirusach było kluczowym krokiem na drodze do odkrycia struktury DNA. Gamow i Delbrück mogą słusznie być traktowani jako założyciele współczesnej kosmologii i genomiki.

Mimo że każdy z nich pomógł zainicjować rewolucję w nauce, Segrè nie myśli o nich w kategoriach jakichś nadzwyczajnych geniuszy. W ocenie autora Gamow i Delbrück nie są jak trzej inni naukowcy, którzy przyczynili się do uformowania mechaniki kwantowej: Wolfgang Pauli, Werner Heisenberg i Paul Dirac. Za pracę, którą wykonali, nie otrzymali Nagrody Nobla w bardzo młodym wieku, nie przyznano im prestiżowych katedr w młodości, nie okrzyknięto ich także liderami w swoich dziedzinach przed trzydziestym rokiem życia. Ich wczesne publikacje nie wywołały takiego rozgłosu, jak prace Francisa Cricka i Jamesa D. Watsona czy Alberta Einsteina. Mimo to ich praca wywarła trwały wpływ i zasadniczo zmieniła współczesną naukę. Pauli, Heisenberg, Dirac i oczywiście Einstein byli nadzwyczajnymi geniuszami, podczas gdy Gamow i Delbrück byli, zdaniem autora, tylko zwykłymi geniuszami, bardziej inteligentnymi i pomysłowymi niż Ty i Ja, ale nie jakościowo innymi niż my (zob. s. XVII-XVIII). Segrè, za sławnym matematykiem Markiem Kacem, zrobił rozróżnienie, porównując zwykłych geniuszy z magikami. Pisze:

To są osoby, których wynalazki są tak pomysłowe, że jest trudne do dostrzeżenia, jak jakikolwiek śmiertelnik mógł je sobie wyobrazić. Jednakowoż nie są oni najbardziej wpływowymi twórcami. W sprzyjających okolicznościach, dzięki wytrwałości, charakterowi i, nie powinniśmy zapomnieć, szczęściu, nawet zwykli geniusze mogą doprowadzić do rewolucji w nauce (s. XVIII).

Dlatego też obaj cieszą się takim uznaniem.

Jednym z powodów, dla których Gamow i Delbrück są autorowi tak bliscy, jest wielkość tego, co osiągnęli. Ale są także inne powody, dla których uważa ich za tak wartościowych. Bardzo docenia ich wielki wysiłek badawczy. Szczególne wrażenie robi na autorze uwaga uczyniona przez 
Alfreda Hersheya, biologa, który dzielił Nagrodę Nobla z Delbrückiem. W przekonaniu Hershey’a Delbrück kierował swoje myśli ku wielkim pytaniom, jeszcze zanim mogły być wyrażone za pomocą słów. Niewielu naukowców potrafi to zrobić. Te słowa pasują jednakowo dobrze do Gamowa, który zawsze przewyższał swoich rówieśników wiekiem. Bycie takim wymaga niezwykłej intuicji. Tę cechę Segrè dostrzega i podziwia zarówno u jednego, jak i drugiego. Jest także coś, co posiadali, za co Autor ceni ich nawet bardziej: intelektualna odwaga. Każdy miał jej pod dostatkiem. Obaj byli też bardzo pozytywnie nastawieni do życia.

Książka Gino Segrègo jest niezwykle cenną pozycją, ukazującą życie i karierę naukową dwóch wybitnych postaci z najnowszej historii nauki. Ten ceniony specjalista i utalentowany pisarz $\mathrm{w}$ nowym świetle rysuje $\mathrm{w}$ tym kontekście przed czytelnikiem dwie doniosłe rewolucje $\mathrm{w}$ dwudziestowiecznej nauce. Poszczególne rozdziały, choć jest ich sporo, bo aż 45, nie są obszerne, a przez to odpowiednio „dawkują” lekturę materiału zawartego w opracowaniu. Książka napisana jest przez profesora fizyki i astronomii, a więc fachowca w dziedzinie nauk przyrodniczych, co pomnaża jej wartość, zaś język jej jest bardzo przystępny i dzięki temu jej lektura nie wymaga szczególnego specjalistycznego przygotowania. Aby w pełni zrozumieć jej treść, wystarczy znajomość nauk przyrodniczych na poziomie szkoły średniej. Szczególnego podkreślenia wymagają źródła, do których odwołuje się autor, niektóre trudno dostępne czy wręcz niedostępne dla ogółu czytelników. Zachęcam do lektury Ordinary Geniuses. 